\title{
Optimalisasi Pendayagunaan Zakat dalam Pelaksanaan Program Pembangunan Berkelanjutan (SDGs)
}

\author{
Farhan Amymie ${ }^{1 *}$, Yaya $1^{1}$, Dewi Sadiah $2^{2}$ \\ 123Jurusan Manajemen Dakwah, Fakultas Dakwah dan Komunikasi, UIN Sunan Gunung Djati, \\ Bandung \\ *Email: Farban.amymie@student.uinsgd.ac.id
}

\begin{abstract}
ABSTRAK
Kesejahteraan akan dapat diminimalisir apabila ada distribusi pendapatan dan kekayaan yang merata. Maka Zakat merupakan salah satu instrument ampuh untuk memberikan solusi pembangunan dan pemerataan ekonomi secara adil dan bijaksana. Apabila dilakukan secara optimal dalam penghimpunan, pengorganisasian zakat harus dilakukan secara efektif dengan dukungan regulasi dan aparat yang professional. Adapun tujuan dari penelitian ini adalah (1) untuk mengetahui sistem pengelolaan dana zakat di Baznas Jawa Barat. (2) Untuk Mengetahui Keterkaitan SDGs dengan Tujuan Zakat. (3) Untuk Mengetahui Hasil dari Rencana Strategis Optimalisasi Pendistribusian Dana Zakat dalam Pencapaian Sustainable Development Goals (SDGs) di Baznas Provinsi Jawa Barat. Metode yang digunakan dalam penelitian ini adalah pendekatan kualitatif, dengan jenis penelitian lapangan (field research). Pengumpulan data dilakukan dengan wawancara, observasi dan dokumentasi. Adapun subjek penelitian adalah para Pimpinan dan staff Baznas Jawa Barat.Setelah data diperoleh kemudian dianalisis kemudian dicek keabsahan data dengan cara reduksi data, penyajian data, dan penarikan kesimpulan. Dalam penelitian ini peneliti membatasi lingkup pengoptimalan distirbusi dan pendayagunaan dana zakat yang diteliti, yaitu diambil dari: (1) Sistem pengelolaan, dan (2) Strategi penguatan peran. Adapun hasil yang ditemukan dari penelitian ini yaitu: (1) Dalam Pengelolaan Zakat BAZNAS Propinsi berkedudukan di Ibukota Provinsi yang bersangkutan dan melakukan pengumpulan zakat melalui UPZ yang ada di provinsi (2) Strategi Penguatan Pendistribusian dan Pendayagunaan BAZNAS Jawa Barat yakni dengan irisan program SDGs dan zakat bertemu dalam sebuah objektif untuk mengurangi kemiskinan termasuk kelaparan yang terjadi di dunia ini dan aneka turunannya. Beberapa pendapat dan pandangan muncul mencoba mengaitkan satu per satu dari poin-poin SDGs dengan interpretasi atas kerja zakat khususnya dari sudut penerima manfaat dan peruntukkan zakat.
\end{abstract}


Kata Kunci : Optimalisasi Dana Zakat; Pendistribusian Zakat; Pendayagunaan Zakat.

\section{ABSTRACT}

Welfare will be minimized. So Zakat is one of the powerful instruments to provide development solutions and economic checks that are fair and wise. If carried out optimally in the collection, organizing zakat must be carried out effectively with professional regulatory and supervisory support. As the purpose of this study, First, To study the management system of rakat funds in Barnas West Java. Second, To Know the Linkages of SDGs to the Purpose of Alms. Third, To Know the Results of the Strategic Plan for the Optimization of Zakat Funds in Achieving Sustainable Development Goals (SDGs) in National Barnas West Java Province. The method used in this study is qualitative research, with the type of field research (field research). Data collection is done by interviews, collection and arrangement. While the research subjects were the West Java Baznas Leaders and staff. After the data is obtained then analyzed then the validity of the data is checked by means of data reduction, data presentation, and discussed conclusions. In this study, this study discusses optimization of the utilization and utilization of zakat funds collected, which are taken from: (1) Management system, and (2) Role strengthening strategy. The following results found from this study are: (1) In the Management of Provincial Zakat BAZNAS located in the Capital of the Province needed and zakat through UPZ in the province (2) West Java BAZNAS Distribution and Utilization Strategy is provided with SDGs slice and zakat fulfill the goal of reducing poverty, including what happens in this world and its various derivatives. Some opinions and opinions that appear link one by one from SDGs points to the interpretation of the special qakat work from the point of view of beneficiaries and zakat allocation.

Keywords: Zakati Fund Optimalisas; Distribution of Zakat; Utilization of Zakat.

\section{PENDAHULUAN}

Undang-Undang Nomor 38 tahun 1999 tentang Pengelolaan Zakat telah melahirkan paradigma baru pengolaan zakat yang diantara lain mengatur bahwa pengelolaan zakat dilakukan oleh Badan Amil Zakat (BAZ) yang dibentuk pemerintah yang terdiri dari unsur masyarakat dan Pemerintah dan Lembaga Amil Zakat (LAZ) yang sepenuhnya dibentuk oleh dan dari masyarakat. Dengan lahirnya paradigma baru ini, maka semua lembaga amil zakat harus menyesuaikan diri dengan amanat undang-undang yakni pembentukannya berdasarkan kewilayahan pemerintah negara mulai dari tingkat nasional, provinsi, kabupaten/kota dan kecamatan.

Zakat merupakan salah satu dari 5 nilai instrumental yang strategis dan sangat berpengaruh pada tingkah laku ekonomi manusia. Dikutip dalam Abdurrachman Qadir (2001). Tujuan zakat sendiri tidak sekedar menyantuni orang miskin secara konsumtif, tetapi mempunyai tujuan yang lebih permanen 
yaitu mengentaskan kemiskinan.

Badan Amil Zakat Nasional (BAZNAS) merupakan organisasi pusat yang dibentuk pemerintah dalam pengelolaan dana zakat. Menjadi induk organisasi merupakan hal yang menjadikan BAZNAS seharusnya sebagai pengelola terpusat. BAZNAS belum mencapai visinya yaitu menjadi pilihan utama Muzakki untuk berzakat di BAZNAS Jawa Barat (Wardani, 2017).

BAZNAS Provinsi Jawa Barat dibentuk oleh Menteri Agama atas usul gubernur setelah mendapat pertimbangan BAZNAS Pusat. BAZNAS Provinsi bertanggung jawab kepada BAZNAS Pusat dan pemerintah daerah provinsi.

Baznas Provinsi Jawa Barat masa kepengurusan baru dibentuk dan dikukuhkan atas dasar Keputusan Gubernur Jawa Barat Nomor 450.12/Kep.156-Yansos/2015 tentang Pimpinan Badan Amil Zakat Nasional (BAZNAS) Provinsi Jawa Barat Periode 2014 s/d. 2019.

Badan Amil Zakat Nasional Jawa Barat dalam kepengurusan hari ini memiliki VISI "Menjadi Pengelola Zakat yang Unggul dan Terpercaya di Tingkat Nasional". Juga dalam melaksanakan VISI nya BAZNAZ Jabar memiliki beberapa MISI yakni; (1) Meningkatkan partisipasi masyarakat dalam berdonasi ZIS untuk mencapai target-target nasional. (2) Mengoptimalkan peran pendayagunaan zakat melalui program kemandirian masyarakat untuk meningkatkan dampak pembangunan dan kepercayaan publik. (3) Mengkoordinasikan pengelolaan zakat se-Jawa Barat untuk meningkatkan soliditas organisasi dan sinergi program.

Salah satu yang menjadi masalah selama ini antara lain adalah masalah pengelolaan zakat yang belum dilakukan secara professional sehingga pengumpulan dan penyaluran zakat menjadi kurang terarah. Padahal sejatinya bila dana zakat dapat di kelola secara maksimal dana tersebut dapat mendorong program pembangunan berkelanjutan atau yang biasa disebut Sustainable Development Goals (SDGs), yang sekarang program tersebut menjadi program baru Pemimpin 193 Negara, PBB, Bank Dunia dan organisasi-organisasi nirlaba di UN Summit New York yakni tentang Tujuan Pembangunan Berkelanjutan yang di sebut sebagai Agenda 2030, meneruskan agenda Milenium Development Goals (MDGs) yang telah berakhir pada Desember 2015.

Grand Desain utama dari Tujuan pembangunan berkelanjutan adalah Kesejahteraan hidup, kesejahteraan hidup yang menunjang di dunia adalah adanya kesejahteraan sosial-ekonomi. Ini merupakan seperengkat alternatif untuk mensejahterakan umat islam dari kemiskinan dan kemelaratan. Untuk itu perlu di bentuk lembaga-lembaga sosial islam sebagai upaya menangulangi masalah sosial tersebut. Sehubungan dengan hal itu, maka zakat dapat berfungsi sebagai salah satu sumber dana sosial-ekonomi bagi umat islam. Artinya pendayagunaan zakat yang dikelola oleh Badan Amil Zakat atau Lembaga Amil Zakat tidak hanya 
terbatas pada kegiatan-kegiatan tertentu saja yang berdasarkan pada orientasi konvensional, tetapi dapat pula dimanfaatkan untuk kegiatan-kegiatan yang mensejahtrakan sosial-ekonomi umat dan pembangunan ekonomi.

Kesejahteraan sosial sendiri dalam artian yang sangat luas, mencakup dalam berbagai tindakan yang dilakukan oleh individu ataupun organisasi untuk mencapai taraf hidup yang lebih baik. Hal ini terlihat dari definisi yang dikemukakan oleh Friedlander (1982: 4): "Social welfare is the organized system of social services and institutions, design to aid individuals and group to attain satisfying standar life and bealt' (Kesejahteraan sosial merupakan sistem yang terorganisir dari institusi dan pelayanan sosial, yang dirancang untuk membantu individu atau pun kelompok agar dapat mencapai standar hidup dan kesehatan yang lebih memuaskan).

Dalam hal ini, kesejahteraan sosial berkaitan dengan organisasi atau institusi pelayanan. Artinya, dengan adanya lembaga atau institusi yang ada dimasyarakat dapat menciptakan atau meningkatkan kesejahteraan sosial melalui pelayananan-pelayananan yang diberikan oleh institusi atau lembaga tersebut. Pelayanan inilah yang nantinya dapat memaksimalkan akses masyarakat dalam meningkatkan kesejahteraan hidup mereka.

Berdasarkan data diatas, kita dapat melihat bahwa dalam penyelenggaraan pendayagunaan zakat di butuhkan persiapan yang matang dan pelaksanaan yang optimal pula. Maka dari itu, penulis tertarik untuk meneliti tentang Pendistribusian Dan Pendayagunaan Zakat Dalam Pencapaian Sustainable Development Goals.

\section{LANDASAN TEORITIS}

Dalam Kamus Besar Bahasa Indonesia pengumpulan berasal dari kata dasar kumpulan yang berarti sesuatu yang telah dikumpulkan, himpunan, kelompok sedangkan pengumpulan itu sendiri mempunyai arti mengumpulkan atau penghimpunan (Andarini \& Amrullah, 2010: 803). Jadi pengumpulan zakat dapat diartikan suatu kegiatan mengumpulkan atau menghimpun dana zakat, dalam hal ini tidak hanya zakat saja tetapi juga infaq dan shadaqah. Pengumpulan zakat didasarkan pada firman Allah dalam surat At-Taubat ayat 103 yang berbunyi artinya: "Ambillah qakat dari sebagian harta mereka, dengan qakat itu kamu membersibkan dan mensucikan mereka dan mendoalah untuk mereka. Sessunggubnya doa kamu itu (menjadi) ketenteraman jiwa bagi mereka dan Allah Maha mendengar lagi Maha mengetabui”.

Dalam firman Allah ini telah memerintahkan kepada mahluk-Nya untuk memungut atau mengambil zakat dari sebagian harta para muzakki untuk diberikan kepada mustahik zakat. Zakat ini dipergunakan selain untuk dimensi ibadah yaitu sebagai salah satu rukun Islam juga sebagai dimensi sosial yaitu untuk memperkecil jurang pemisah antara orang kaya dan orang miskin, 
mengembangkan solidaritas sosial, menghilangkan sikap materialisme dan individualisme. Pada masa Khulafaur-Rasyidin mempunyai petugas khusus yang mengatur masalah zakat, baik yang mengambil maupun yang mendistribusikannya.

Diambilnya zakat dari muzakki (orang yang memiliki kewajiban zakat) melalui amil zakat untuk kemudian disalurkan kepada, ini menunjukkan bahwa kewajiban zakat itu bukanlah semata-mata bersifat amal karitatif (kedermawanan), tetapi juga suatu kewajiban yang bersifat otoritatif (ijbari) (Didin Hafidudin. 2002: 126). Pola pengelolaan zakat di Indonesia telah dilakukan sejak Indonesia belum merdeka. Pada masa penjajahan belanda pelaksanaan ajaran Islam (termasuk zakat) diatur dalam ordonantie pemerintah Hindia-Belanda Nomor 6200 tanggal 28 Pebruari 1905. Dalam pengaturan ini pemerintah tidak mencampuri masalah pengelolaan zakat dan menyerahkan sepenuhnya kepada umat Islam serta bentuk pelaksanaannya sesuai syariat Islam.

Ketika Indonesia merdeka pemerintah melegalkan pengelolaan zakat dengan Undang-Undang No.23 Tahun 2011 tentang pengelolaan zakat dengan keputusan menteri agama (KMA) No.581 Tahun 1999 tentang pelaksanaan UU No. 23 Tahun 2011 dan Keputusan Direktur Jendral Bimbingan Masyarakat Islam dan Urusan Haji No. D/291 Tahun 2000 tentang pedoman teknis pengelolaan zakat (Hasan, 2011: 14).

Maqashid Syariah merupakan sebuah tujuan dari implementasi syariat (hukum Islam) dalam kehidupan sehari-hari (Kamili, 2008). Konsep ini menjadi sebuah konsepsi berfikir yang melekat pada pembangunan teori dan praktik ekonomi dan keuangan Islam. Sebuah konsep yang sangat komprehensif dalam mengatur bagaimana seharusnya ekonomi Islam dibangun baik dalam tataran mikro maupun makro.

Maqashid Syariah dibangun di atas sebuah asumsi dasar bahwa syariat yang telah Allah Sang Pembuat Syariat tetapkan melalui sumber-sumber utama ontologi Islam, yakni Al-Qur'an dan Sunnah, dibangun di atas tujuan pencapaian kemaslahatan, bukan hanya bagi individual melainkan juga sosial (Q.S. 21: 107 dan Q.S. 10: 57). Maka dari itu, sumber-sumber turunan di bawah sumber utama otologi Islam tersebut juga harus merujuk pada pencapaian maqashid syariah individu dan masyarakat secara luas, bukan hanya menggunakan pendekatan fiqih klasik (Ebrahim, et al., 2016).

Terkait dengan itu, argumen Ebrahim et al bahwa pembangunan ekonomi dan sosial dewasa ini perlu mengikuti ijtihad yang dinamis berlandaskan pada maqashid syariah, bukan hanya sekadar fiqih klasik, adalah sangat relevan. Selain dapat sesuai dengan tujuan syariah, hal ini juga mendorong terciptanya iklim pembangunan yang inovatif dan dinamis. Namun demikian, untuk mencapai hal tersebut definisi dan kerangka kerja yang pasti dan jelas terkait dengan maqashid 
syariah perlu dibangun.

Secara bahasa maqashid merupakan bentuk plural dari maqsid yang artinya maksud, tujuan, prinsip atau pokok, niatan, sasaran, atau tujuan akhir (Ibn Ashur, Mohammad al-Tahir. 2006). Ketika dipadankan dengan syariah, maqashid syariah berarti tujuan akhir (prinsip) dari hukum Islam (Ibn Ashur, Mohammad al-Tahir, 2006).

Tujuan tersebut kemudian oleh Najmuddin al-Tufi digeneralisasi dengan sebuah kata yang mencakup banyak dimensi, yakni maslahah (Auda, Jasser. 2008) Al-Tufi mendefinisikan maslahah sebagai suatu hal yang luas, mencakup segala kepentingan yang dimiliki oleh sosial (social interest). Shihabuddin al-Qarafi dalam Al - Dhakheerah mendefinsikan maslahah sebagai suatu hal yang maqashid syariah tidaklah tercapai tanpa pemenuhan hal tersebut (Auda, Jasser: 2008).

Selanjutnya Pendayagunaan berasal dari kata guna yang berarti bermanfaat. Adapun pengertian pendayagunaan sendiri menurut Kamus Besar Bahasa Indonesia adalah berusaha agar mampu mendatangkan hasil dan manfaat, pengusaha (tenaga dan sebagainya) agar mampu menjalankan tugas dengan baik. Pendayagunaan adalah bagaimana cara atau usaha dalam mendatangkan hasil dan manfaat yang lebih besar serta lebih baik. Ada dua bentuk penyaluran dana zakat antara lain, (1) Bentuk Sesaat, berarti zakat hanya diberikan kepada seseorang atau satu kali atau sesaat saja. Dalam hal ini juga berarti bahwa penyaluran kepada mustahik tidak disertai target terjadinya kemandirian ekonomi dalam diri mustahik. Hal ini dikarenakan mustahik yang bersangkutan tidak mungkin lagi mandiri, seperti pada diri orangtua yang sudah jompo, orang cacat, sifat bantuan sesaat ini idealnya adalah hibah. (2) Bentuk Pemberdayaan, penyaluran zakat iini disertai target merunah keadaan penerima dari kondisi kategori mustahik menjadi kategori muzaki. Target ini sangat besar yang tidak dapat dengan mudah dan dalam waktu yang singkat. Untuk itu, penyaluran zakat harus disertai dengan pemahaman yang utuh terhadap permasalahan yang ada pada penerima. Apabila permasalahannya adalah kemiskinan, harus dikeahui penyebab kemiskinan tersebut, sehingga dapat dicarikan solusi yang tepat demi tercapainya target yang telah dicanangkan (Kementrian Agama: 2012: 43-44).

Pendayagunaan sendiri, ada yang namanya pendayagunaan konsumtif yang diperuntukan bagi pemenuhan hajat hidup para mustahik yang delapn asnaf sesuai dengan penjelasan undang-undangyang didalam aplikasinya dapat meliputi orang-orang yang paling tidak berdaya secara ekonomi yang dibagi menjadi dua bagian, yaitu, (1) Konsumtif tradisional, yaitu zakat yang dibagikan kepada mustahik untuk diberikan langsung seperti zakat fitrah untuk memenuhi kebutuhan sehari-hari atau zakat mal (harta) yang dibagikan habis langsung kepada para mustahik. (2) Konsumtif kreatif, yaitu zakat yang diwujudkan dalam bentuk lain dari barangnya semula, seperti diberikan dalam bentuk alat-alat sekolah, beasiswa, dan lain sebagainya. 
Kemudian ada juga pendayagunaan produktif yang diperuntukan bagi usaha produktif apabila kebutuhan mustahik delapan asnaf sudah terpenuhibdan terdapat kelebihan. Pendayagunaan dana infaq, shodaqoh, hibah, wasiat, waris, dan kafarat diutamakan untuk usaha yang produktif agar dapat meningkatkan kesejahteraan masyarakat, penyaluran zakat dalam bentuk ini adalah bersifat bantuan pemberdayaan melalui program atau kegiatan yang berkesinambungan.

Sama halnya dengan pendayagunaan konsumtif, pendayagunaan ini juga dibagi menjadi dua dengan penamaan yang sama namun konteks yang berbeda, yakni: (1) Produktif tradisional, dimana zakat diberikan dalam bentuk barangbarang yang produktifseperti kambing, sapi, alat cukur, pertukangan, mesin jahit, dan lain-lain. Pemberian dalam bentuk ini akan dapat menciptakan suatu usaha atau memberikan lapangan pekerjaan baru bagi fakir miskin. (2) Produktif kreatif, yaitu zakat diwujudkan dalam bentuk permodalan bergulir baik untuk permodalan kegiatan sosial atau untuk membantu menambahkan modal pedagang atau pengusaha kecil.

Pemberian modal kepada perorangan harus dipertimbangkan dengan matang oleh amil. Apakah mampu orang tersebut mengolah dana yang diberikan itu, sehingga pada suatu saat dia tidak lagi menggantungkan hidupnya kepada orang lain, termasuk mengharapkan zakat. Apabila hal ini dpat dikelola dengan baik atas pengawasan dari amil (bila memungkinkan) maka secara berangsurangsur, orang yang tidak punya (melarat) akan terus berkurang dan tidak tmenutup kemungkinan dia pun bisa menjadi muzakki, bukan sebagai mustahik lagi.

Adapun Istilah pendistribusian, berasal dari kata distribusi yang berarti penyaluran atau pembagian kepada beberapa orang atau beberapa tempat. Oleh karena itu, kata ini mengandung makna pemberian harta zakat kepada para mustahik zakat secara konsumtif. Sedangkan, istilah pendayagunaan berasal dari kata daya-guna yang berarti kemampuan mendatangkan hasil atau manfaat. Istilah pendayagunaan dalam konteks ini mengandung makna pemberi zakat kepada mustahik secara produktif dengan tujuan agar zakat mendatangkan hasil dan manfaat bagi yang memproduktifkan. Pemberian zakat pada mustahik, secara konsumtif dan produktif perlu dilakukan sesuai kondisi mustahik. Untuk mengetahui kondisi mustahik, amil zakat perlu memastikan kelayakan para mustahik, apakah mereka dapat dikategorikan mustahik produktif atau mustahik konsumtif.

Ini memerlukan analisis tersendiri oleh para amil zakat, sehingga zakat benar-benar sampai kepada orang-orang yang berhak menerimanya secara objektif. Penyaluran zakat dilihat dari bentuknya dapat dilakukan dalam dua hal yakni bentuk sesaat dan bentuk pemberdayaan. Penyaluran bentuk sesaat adalah penyaluran zakat hanya diberikan kepada seseorang sesekali atau sesaat saja. 
Dalam hal ini, juga berarti bahwa penyaluran kepada mustahik tidak disertai target terjadinya kemandirian ekonomi dalam diri mustahik. Hal ini dikarenakan mustahik yang bersangkutan tidak mungkin lagi mandiri, seperti pada diri orang tua yang sudah jompo, dan orang cacat.

Penyaluran bentuk pemberdayaan merupkan penyaluran zakat yang disertai target merubah kondisi mustahik menjadi kategori muzzaki. Target ini adalah target besar yang tidak dapat dengan mudah atau dalam waktu yang singkat, dapat terealisasi. Karena itu, penyaluran zakat harus disertai dengan pemahaman yang utuh terhadap permasalahan yang ada pada penerima.

Apabila permasalahannya adalah permasalahan kemiskinan, harus diketahui penyebab kemiskinan tersebut, sehingga dapat mencari solusi yang tepat demi tercapainya target yang telah direncanakan. Pendistribusian zakat adalah inti dari seluruh kegiatan pengumpulan dana zakat. Di dalam mengoptimalkan fungsi zakat sebagai amal ibadah sosial mengharuskan pendistribusian zakat diarahkan pada model produktif dari pada model konsumtif seperti ketentuan yang tercantum dalam UU No. 38 Tahun 1999 tentang pengelolaan zakat. Dalam pelaksanaannya, model pendayagunaan zakat pada penyaluran dana diarahkan pada sektor-sektor pengembangan ekonomi dengan harapan hasilnya dapat mengangkat taraf kesejahteraan mustahik.

Adapun Pendayagunaan berasal dari kata guna yang berarti bermanfaat. Adapun pengertian pendayagunaan sendiri menurut Kamus Besar Bahasa Indonesia adalah : berusaha agar mampu mendatangkan hasil dan manfaat, pengusaha (tenaga dan sebagainya) agar mampu menjalankan tugas dengan baik.

Pemberian modal kepada perorangan harus dipertimbangkan dengan matang oleh amil. Apakah mampu orang tersebut mengolah dana yang diberikan itu, sehingga pada suatu saat dia tidak lagi menggantungkan hidupnya kepada orang lain, termasuk mengharapkan zakat. Apabila hal ini dpat dikelola dengan baik atas pengawasan dari amil (bila memungkinkan) maka secara berangsurangsur, orang yang tidak punya (melarat) akan terus berkurang dan tidak tmenutup kemungkinan dia pun bisa menjadi muzakki, bukan sebagai mustahik lagi (Kementrian Agama, 2012: 43-44).

Selanjutnya, tujuan pembangunan berkelanjutan yakni, dalam tatanan yang lebih luas, dunia juga sedang mencari tujuan-tujuan bersama yang disepakati untuk dipenuhi oleh seluruh negara. Pencarian tersebut terinisiasi dengan heroik pada tahun 2000, di mana Millenium Development Goals (MDGs) disepakati oleh negara-negara di dunia. Tujuan di masa millennium itu disepakati untuk dicapai pada tahun 2015. Fokus dari tujuan tersebut lebih banyak pada pengentasan kemiskinan ekstrim di dunia.

Namun, faktanya MDGs belum dapat memberikan perbedaan yang berarti dalam mengambil peran memberantas kemiskinan. Banyak negara-negara, khususnya di Benua Afrika, yang masih sangat jauh tertinggal dan tidak dapat 
mencapai targetnya. Indonesia juga menjadi salah satu negara yang gagal dalam mewujudkan MDGs, utamanya dalam hal menurunkan Angka Kematian Ibu (AKI) dan Angka Kematian Bayi Baru Lahir (AKB). Peneltiian menyebutkan bahwa permasalahan utama dari MDGs adalah target yang tidak rasional dan mobilisasi sumber daya (resource mobilization) yang tidak berjalan dengan baik (Fehling, Maya., Nelson, Brett D., Venkatapuram, Sridhar. 2013: 1109-1122). Hal tersebut diperparah dengan tidak dipertimbangkannya isu-isu dan karakterisitk yang berbeda antara satu negara dengan negara yang lain.

Indonesia juga menjadi stakeholder yang menyetujui dan berkomitmen untuk mewujudkan SDGs tersebut. Negara terbesar di ASEAN melalui BAPPENAS memandang SDGs sebagai pembangunan yang menjaga peningkatan kesejahteraan ekonomi masyarakat secara berkesinambungan, keberlanjutan kehidupan sosial masyarakat, kualitas lingkungan hidup serta menjamin keadilan dan terlaksananya tata kelola yang mampu menjaga peningkatan kualitas hidup dari satu generasi ke generasi berikutnya (BAPPENAS, 2016).

Kemudian, Untuk memastikan pengelolaan zakat sesuai dengan nilai-nilai fundamental yang dimiliki oleh ekonomi Islam, maqasid syariah telah sepantasnya digunakan sebagai basis pertimbangnnya, setidaknya inspirasi dari perspektif maqasid syariah tersebut (Kasri, R. A: 2016: 19-41). Penelitian akhirakhir ini pun konsisten mebawa maqasid syariah sebagai basis dalam penghitungan performa institusi keuangan. Misalnya Marta yang menggunakan kerangka berfikir maqasid syariah untuk mengukur (Marta, S.S. dan Abdul Fatah, Anwar, 1984: 29-44).

Performa perbankan Islam dan Dusuki yang mengukur performa corporate social responsibility dalam kerangka berfikir maqasid syariah (Dusuki, A.W, 2005). Zakat seharusnya „lebih berhak untuk menggunakan kerangka berfikir maqasid syariah dalam segala prosesnya (Kasri, 2016). Secara fundamental, zakat bukan hanya dapat memenuhi legal dan substansi dari syariat melainkan juga relatif lebih mudah untuk mempromosikan wajah sosial dan keberpihakan pada sektor rill dari syariah itu sendiri.

\section{HASIL DAN PEMBAHASAN}

Penelitian ini dilakukan di Badan Amil Zakat Nasional Provinsi Jawa Barat. Rute menuju Baznas Provinsi Jawa Barat ini dapat ditempuh menggunakan kendaraan roda dua maupun roda empat. Lokasi Badan Amil Zakat Nasional ini cukup mudah ditemukan karena berada di area perkotaan.

Visi dan Misi Baznas Jawa Barat telah ditetapkan dalam Renstra Baznas Jawa Barat 2012-2016 sebagai berikut: Visi Baznas Jawa Barat adalah "Menjadi institusi zakat yang unggul, terpercaya serta menjadi salah satu pilar terdepan 
pemberdayaan sosio-ekonomi umat". Visi ini mengandung pengertian umum bahwa Baznas Provinsi Jawa Barat ingin lebih mengedepankan pemberdayaan pada sosial ekonomi umat berbasis zakat maupun non zakat (infaq, shadaqah, hibah, hadiah dll.) Pencapaian visi tersebut, dilakukan melalui 4 pilar/Misi, yaitu: (1) Membangun Jawa Barat sebagai Zakat Provinsi Zakat; (2) Melaksanakan dakwah zakat; (3) Meningkatkan peran sosio ekonomi umat; (4) Menjadi institusi profesional berbasis teknologi informasi terkini.

Baznas mengembangkan suatu tata nilai yang baik akan membentuk karakter yang baik terhadap pelayanan dan sistem manajemen institusi Baznas Provinsi Jawa Barat. Tata nilai yang dijunjung tinggi Baznas Jawa Barat, merupakan modal dasar intrinsik yang sangat substansial bila dikaitkan dengan upaya mempertahankan keberlangsungan, pencapaian tujuan dan pencitraan kelembagaan yang mendorong terciptanya kepercayaan umat. Tata nilai yang tengah dibina dan dikembangkan yaitu profesionalisme dalam pengelolaan, istiqamah dalam amanah dan kemandirian dalam kebersamaan.

Dalam suatu kelompok/kumpulan, perlu akan adanya suatu proses pengorganisasian. Karena pengorganisasian membahas mengenai siapa mengerjakan apa, tanggung jawabnya seperti apa, alur pengerjaanya bagaimana, sehingga jelas orang yang ada didalamnya tugas dan fungsi dalam kelompok tersebut. Disamping itu, dalam kelompok memiliki tujuan masing-masing yang ingin dicapai. Oleh karena itu suatu kelompok perlu akan adanya suatu pengorganisasian agar jelas arah dan tujuannya.

Apalagi ini menyangkut dana zakat, infak, sodaqah, dan wakaf yang harus dikelola dan disalurkan sebaik mungkin agar tidak terjadi salah sasaran dalam penyalurannya. Ketika melihat tujuan dari penghimpunan zakat bisa memberikan dampak bagi kesejahtraan masyarakat, hal ini menjadi suatu dambaan masyarakat kecil yang memiliki keinginan untuk memperbaiki kehidupan ke yang lebih mapan baik secara ruhani maupun secara materi. Maka zakat diharapkan bisa menjadi solusi bagi permasalahan yang ada di masyarakat tentunya dengan adanya pengelolaan serta pengorganisasian yang baik dan terarah.

Sejauh ini dana zakat, infak, sodaqah, dan wakaf yang himpun oleh BAZNAS Jawa Barat dalam proses penyaluran dana Zakat di organisasikan secara hati-hati sehingga dana ini bisa sampai kepada haknya dan tujuannya pun bisa tercapai dengan harapan mustahik bisa menjadi muzaki selanjutnya. Hal ini di tandai dengan adanya assessment terlebih dahulu sebelum di salurkan kepada para mustahik dan adanyanya beberapa persyaratan dalam pengajuan yang harus dipenuhi oleh pihak yang bersangkutan sebagai tanda dokumen yang menunjukan dan menjadi bukti bukan dalam artian mempersulit untuk mendapatkan bantuan tetapi menyangkut dana zakat merupakan amanah supaya bisa tersampaikan kepada yang haknya.

Selain memandang dari proses penerima manfaat, staf atau pegawai 
didalamnya yang mengatur dana Zakat dilakukan pengorganisasian dengan ditandai adanya Job Description masing-masing. Dari mulai yang bertugas mengelola keuangan, pelayanan zakat, penghimpunan sampai yang bertugas dalam penyaluran zakat. Itu semua dijalankan dengan tanggung jawab masingmasing yang telah di bebankan oleh lembaga atau intansi dan dari gambaran tersebut jelas tugas fungsinya seperti apa.

Program-program yang dikeluarkan oleh BAZNAS Jawa Barat pun tidak terlepas dari proses manajemen salah satunya dilakukannya pengorganisasian. Ini dilakukan ketika program di rancang sampai pelaporan atau pengkoordinasian program tersebut sebelum di luncurkan. Dalam proses perancangan di bahas tentang siapa yang bertanggungjawab di dalamnya serta tugas, targetnya apa, sasaran, fasiltas dan stanar operasioanalnya seperti apa. Sehingga program tersebut bisa tersusun secara terarah dan terorganisir

Hasil dari penelitian yang dilakukan di Badan Amil Zakat Provinsi Jawa Barat, peneliti mendapatkan hasil bahwa Optimalisasi Pendistribusian dan Pendayagunaan Dana Zakat dalam Pelaksanaan Tujuan Program Pembangunan Berkelanjutan, dalam pelaksanaannya di lapangan dapat dikatakan cukup baik, walaupun masih ada kekurangan yang perlu untuk diperhatikan lagi sebagai usaha perbaikan ke depannya nanti.

\section{Sistem Pengelolaan Dana Zakat Oleh Badan Amil Zakat Nasional}

Menurut Undang-Undang No.23 Tahun 2011 pada BAB I pasal 1 bahwa Unit Pengumpul Zakat (UPZ) adalah satuan organisasi yang dibentuk oleh BAZNAS untuk membantu pengumpulan zakat di setiap instansi, Pasal 2 disebutkan pengumpulan zakat meliputi; Zakat Maal dan Zakat Fitrah. Zakat maal dan tujuan zakat merupakan efektifitas dan efisiensi pelayanan dalam pengelolaan zakat dan meningkatkan manfaat zakat untuk mewujudkan kesejahteraan masyarakat dan penanggulangan kemiskinan (Undang-undang, 2011: 23).

Pendayagunaan zakat harus berdampak positif bagi mustahiq, baik secara ekonomi maupun sosial. Dari sisi ekonomi, mustahiq dituntut benar-benar dapat mandiri dan hidup secara layak sedangkan dari sisi sosial, mustahiq dituntut dapat hidup sejajar dengan masyarakat yang lain. Hal ini berarti, zakat tidak hanya didistribusikan untuk hal-hal yang konsumtif saja dan hanya bersifat charity tetpi lebih untuk kepentingan yang produktif dan bersifat edukatif. Kelemahan utama orang miskin serta usaha kecil yang dikerjakannya sesungguhnya tidak semata-mata pada kurangnya permodalan, tetapi lebih pada sikap mental dan kesiapan manajemen usaha. untuk itu, zakat usaha produktif pada tahap awal harus mampu mendidik mustahiq sehingga benar-benar siap untuk berubah. Karena tidak mungkin kemiskinan itu dapat berubah kecuali dimulai dari perubahan mental si miskin itu sendiri. Inilah yang disebut peran pemberdayaan. 
Zakat yang dapat dihimpun dalam jangka panjang harus dapat memberdayakan mustahiq sampai pada dataran pengembangan usaha. Programprogram yang bersifat konsumtif ini hanya berfungsi sebagai stimulan atau rangsangan dan berjangka pendek., sedangkan program pemberdayaan ini harus diutamakan. Makna pemberdayaan dalam arti yang luas ialah memandirikan mitra, sehingga mitra dalam hal ini mustahiq tidak selamanya tergantung kepada amil.

"Dalam pengumpulan dan pendistribusiannya BAZNAS Jawa Barat itu menjadi Koordinator dari BAZ-BAZ daerah Kabupaten dan Kota juga menjadi Pelaku Pengumpulan dan Pendistribusian Dana Zakat itu sendiri yang menjadi beda dengan BAZ-BAZ daerah yakni pada wilayah cakupan BAZNAS Jawa barat melingkupi seluruh daerah Jawa Barat" (Wawancara dengan Bapak Rudi selaku Staff Ahli Pendistribusian BAZNAS Jawa Barat pada tanggal 20 Juni 2018).

BAZNAS memilki 5 (lima) fokus ketegori penyaluran dana, yakni (1) ekonomi; (2) sosial dan kemanusiaan; (3) kesehatan; (4) pendidikan; dan (5) dakwah. Masing-masing fokus tersebut sesuai dengan dimensi maqasid syariah yakni secara berturut-turut (1) Harta; (2) Keturunan; (3) Jiwa; (4) Pendidikan; dan (5) Dakwah. Hal ini perlu dipertahankan dan bahkan disesuaikan terus menerus terhadap perkembangan zaman. Sebagaimana juga maqasid syariah yang sesungguhnya sangat fleksibel penerapannya terhadap perkembangan zaman yang ada.

Juga dalam Penyalurannya BAZNAS Jabar membagi presentasi pendistribusian dana zakat antara untuk amil dan asnaf yang lainnya yakni,Dana untuk Amil (Dana Penyalur) sekitar 12,5\% dari dana zakat yang terkumpul sedangkan sisanya $87,5 \%$ di peruntukan untuk Dana Program dengan tetap mempertimbangkan asnaf zakat selain dana amil.

Pemberian zakat pada mustahik, secara konsumtif dan produktif perlu dilakukan sesuai kondisi mustahik. Untuk mengetahui kondisi mustahik, amil zakat perlu memastikan kelayakan para mustahik, apakah mereka dapat dikategorikan mustahik produktif atau mustahik konsumtif.

Ini memerlukan analisis tersendiri oleh para amil zakat, sehingga zakat benar-benar sampai kepada orang-orang yang berhak menerimanya secara objektif. Penyaluran zakat dilihat dari bentuknya dapat dilakukan dalam dua hal yakni bentuk sesaat dan bentuk pemberdayaan. Penyaluran bentuk sesaat adalah penyaluran zakat hanya diberikan kepada seseorang sesekali atau sesaat saja. Dalam hal ini, juga berarti bahwa penyaluran kepada mustahik tidak disertai target terjadinya kemandirian ekonomi dalam diri mustahik.

Hal ini dikarenakan mustahik yang bersangkutan tidak mungkin lagi mandiri, seperti pada diri orang tua yang sudah jompo, dan orang cacat. Penyaluran bentuk pemberdayaan merupkan penyaluran zakat yang disertai 
target merubah kondisi mustahik menjadi kata gori muzzaki. Target ini adalah target besar yang tidak dapat dengan mudah atau dalam waktu yang singkat, dapat terealisasi. Karena itu, penyaluran zakat harus disertai dengan pemahaman yang utuh terhadap permasalahan yang ada pada penerima.

Apabila permasalahannya adalah permasalahan kemiskinan, harus diketahui penyebab kemiskinan tersebut, sehingga dapat mencari solusi yang tepat demi tercapainya target yang telah direncanakan. Pendistribusian zakat adalah inti dari seluruh kegiatan pengumpulan dana zakat. Di dalam mengoptimalkan fungsi zakat sebagai amal ibadah sosial mengharuskan pendistribusian zakat diarahkan pada model produktif dari pada model konsumtif seperti ketentuan yang tercantum dalam UU No. 38 Tahun 1999 tentang pengelolaan zakat. Dalam pelaksanaannya, model pendayagunaan zakat pada penyaluran dana diarahkan pada sektor-sektor pengembangan ekonomi dengan harapan hasilnya dapat mengangkat taraf kesejahteraan mustahik.

Dapat saya simpulkan bahwa pengelolaan dana zakat yang dilakukan oleh Baznas sudah sesuai dengan Undang-Undang No. 23 Tahun 2011, hal ini dibuktikan dengan program focus Baznas yang memilki 5 (lima) fokus ketegori penyaluran dana, yakni (1) ekonomi; (2) sosial dan kemanusiaan; (3) kesehatan; (4) pendidikan; dan (5) dakwah. Masing-masing fokus tersebut sesuai dengan dimensi maqasid syariah yakni secara berturut-turut (1) Harta; (2) Keturunan; (3) Jiwa; (4) Pendidikan; dan (5) Dakwah. Kemudian penyalurannya Baznas Jabar membagi presentasi pendistribusian dana zakat antara untuk amil dan asnaf yang lainnya yakni, Dana untuk Amil (Dana Penyalur) sekitar 12,5\% dari dana zakat yang terkumpul sedangkan sisanya 87,5\% di peruntukan untuk Dana Program dengan tetap mempertimbangkan asnaf zakat selain dana amil, pemberian zakat pada mustahik, secara konsumtif dan produktif perlu dilakukan sesuai kondisi mustahik. Untuk mengetahui kondisi mustahik, amil zakat perlu memastikan kelayakan para mustahik, apakah mereka dapat dikategorikan mustahik produktif atau mustahik konsumtif (Undang-undang, 2011: 23).

\section{Strategi Penguatan Peran Badan Amil Zakat Nasional}

Peranan Baznas bisa didefinisikan sebagai pola-pola atau norma-norma perilaku dari orang yang menduduki posisi tertentu dalam struktur sosial, setiap peran sosial adalah serangkaian hak, kewajiban, harapan, norma, dan perilaku seorang yang haus dihadapi dan dipenuhi (Burke, 2011: 71).

Zakat yang dapat dihimpun dalam jangka panjang harus dapat memberdayakan mustahiq sampai pada dataran pengembangan usaha. Programprogram yang bersifat konsumtif ini hanya berfungsi sebagai stimulan atau rangsangan dan berjangka pendek., sedangkan program pemberdayaan ini harus diutamakan. Makna pemberdayaan dalam arti yang luas ialah memandirikan 
mitra, sehingga mitra dalam hal ini mustahiq tidak selamanya tergantung kepada amil.

BAZNAS Propinsi berkedudukan di Ibukota Provinsi yang bersangkutan dan melakukan pengumpulan zakat melalui UPZ yang ada di provinsi tersebut baik itu UPZ pada Kantor Daerah Provinsi dan Instansi Vertikal yang berada di daerah tersebut, UPZ dan BUMD dan BUMN Cabang yang berada di daerah, UPZ pada Perusahaan Swasta dan Unit Usaha milik orang muslim setempatyang berada di bawah koordinasi Provinsi yang bersangkutan dan juga dana zakat Perorangan.

Dalam hal penyaluran dan pendayagunaan zakat, BAZNAS provinsi dapat menyalurkan dana zakat, infaq dan shadaqah ke seluruh provinsi yang bersangkutan disesuaikan dengan lokasi sasaran. Dalam melaksanakan penyaluran dana zakat, infaq dan shadaqah yang berhasil dikumpulkan perlu memprioritaskan mustahiq yang diusulkan oleh UPZ yang telah menyetor ke BAZNAS provinsi tersebut, disamping mustahiq lain yang telah terdata di wilayah masing-masing.

Cuman pada relaliasinya hari ini BAZNAS Jawa Barat perlu bisa mematangkan strategi pengumpulan dana zakat agar BAZNAS Jawa Barat menjadi proritas utama sebagai penyalur dan pendaya guna dana zakat di Jawa Barat, juga strategi dalam penyaluran dana zakat perlu di rapihkan lagi dalam penyalurannya semisal memverifikasi ulang dan menginventarisir mustahik yang benar-benar membutuhkan secara berkala dan melakukan pengawasan dan pembimbingan lanjutan agar dana zakat bisa di manfaatkan semaksimal mungkin oleh para mustahik.

Penyaluran dana Zakat secara nasional kurang lebih telah menyasar 6,806,175 jiwa mustahik. Dari aneka aktifitas pengumpulan dan penyaluran dengan variasinya, kerja-kerja zakat termasuk organisasi-organisasi pengelolanya berupaya untuk mencapai tujuan dari zakat yaitu untuk mensejahterakan dan memberikan keadilan bagi masyarakat khususnya para mustahik/orang-orang yang berhak atas zakat. Pengelolaan zakat secara umum dilakukan melalui program-program dan kegiatan, yang jika dikelompokkan ke dalam bidangbidang, berupa program santunan/ layanan bantuan langsung yang bersifat konsumtif, program pendidikan, program kesehatan, program pemberdayaan masyarakat dan ekonomi masyarakat, serta program kedaruratan, dan lainnya.

PBB (Perserikatan Bangsa-Bangsa) pun telah menginisiasi Tujuan Pembangunan Berkelanjutan atau biasa disebut Sustainability Development Goals (SDGs). SDGs merupakan agenda pembangunan global berkelanjutan yang telah mendapatkan konsensus atau kesepakatan dari 193 negara anggota Perserikatan Bangsa-Bangsa (PBB) dan berkomitmen pada pencapaiannya. SDGs sebagai inisiatif kelanjutan dari platform sebelumnya yaitu Millenium Development Goals (MDGs). 
Pada perkembangannya, terutama di Indonesia dan Jawa Barat para pihak saling melihat potensi-potensi sumber daya termasuk pendanaan untuk pencapaian SDGs dari banyak sektor tak terkecuali zakat. Dilihat dari jenis program yang dilakukan oleh kerja-kerja zakat, tidak terelakkan memiliki irisan yang jelas terhadap tujuan capaian SDGs. Misalnya pengentasan kemiskinan dan kelaparan, pendidikan berkualitas, air dan sanitasi, dll. Oleh karena itu, zakat dapat dikatakan sebagai salah satu instrumen yang memiliki peran dan kontribusi yang strategis bagi capaian SDGs.

Potensi keterkaitan dan irisan antara zakat dengan SDGs seharusnya tidak hanya pada program, melainkan juga dengan para pelaku yang mungkin terlibat, di samping SDGs juga mensyaratkan adanya kerjasama diantara multi stakeholder di masyarakat.

Keterkaitan lainnya juga mungkin muncul dari pendekatan dan cara pengelolaan program, alokasi sumber daya, para beneficiaries/ penerima program Zakat, hingga pertanggungjawaban dan akuntabilitas di dalam mencapai tujuan dan hasil yang diharapkan. Sehingga dalam pelaksanaannya perlu ada kajian mendalam yang terus di kembangkan dalam keilmuannya sekalipun SDGs merupakan suatu kajian yang masih baru yang ada di BAZNAS Jawa Barat.

Kesimpulanya, keterkatian antara pengelolaan dana zakat dan SDGs ini bila di kaji lebih mendalam dapat mengahasilkan pencapaian yang optimal dalam pendistribusian dana zakat juga SDGs ini bisa menjadi gambaran pencapaian kesejahteraan masyarakat dan pengentasan kemiskinan di masyarakat Jawa Barat (Burke, 2011: 71).

\section{PENUTUP}

Berdasarkan temuan dari penelitian yang telah dilaksanakan dan dibahas pada bab-bab sebelumnya, penulis dapat mengambil kesimpulan dari masalah yang penulis bahas yaitu tentang Optimalisasi Pendistribusian dan Pendayagunaan Dana Zakat dalam Pelaksanaan Tujuan Program Pembangunan Berkelanjutan, berdasarkan data yang penulis peroleh maka dapat di ambil kesimpulan sebagai berikut:

Pertama, Dalam Pengelolaan Zakat BAZNAS Propinsi berkedudukan di Ibukota Provinsi yang bersangkutan dan melakukan pengumpulan zakat melalui UPZ yang ada di provinsi tersebut. (1) UPZ pada Kantor Daerah Provinsi dan Instansi Vertikal yang berada di daerah tersebut. (2) UPZ dan BUMD dan BUMN Cabang yang berada di daerah tersebut. (3) UPZ pada Perusahaan Swasta dan Unit Usaha milik orang muslim setempatyang berada di bawah koordinasi Provinsi yang bersangkutan. (4) Perorangan. BAZNAS memilki 5 (lima) fokus ketegori penyaluran dana, yakni (1) ekonomi; (2) sosial dan kemanusiaan; (3) kesehatan; (4) pendidikan; dan (5) dakwah. Masing-masing 
fokus tersebut sesuai dengan dimensi maqasid syariah yakni secara berturut-turut (1) Harta; (2) Keturunan; (3) Jiwa; (4) Pendidikan; dan (5) Dakwah. Hal ini perlu dipertahankan dan bahkan disesuaikan terus menerus terhadap perkembangan zaman. Sebagaimana juga maqasid syariah yang sesungguhnya sangat fleksibel penerapannya terhadap perkembangan zaman yang ada).

Kedua, Strategi Penguatan Pendistribusian dan Pendayagunaan BAZNAS Jawa Barat yakni dengan irisan program SDGs dan zakat bertemu dalam sebuah objektif untuk mengurangi kemiskinan termasuk kelaparan yang terjadi di dunia ini dan aneka turunannya. Beberapa pendapat dan pandangan muncul mencoba mengaitkan satu per satu dari poin-poin SDGs dengan interpretasi atas kerja zakat khususnya dari sudut penerima manfaat dan peruntukkan zakat. Kontribusi Zakat terhadap SDGs saat ini berfokus pada 5 tujuan yaitu Goal 1, Menghapus Kemiskinan, Goal 2, Mengakhiri kelaparan, Goal 3, Kesehatan yang baik dan kesejahteraan, Goal 4, Pendidikan Bermutu, dan Goal 5, Air bersih dan sanitasi. Ada juga pendapat yang menyebutkan bahwa di setiap tujuan SDGs merupakan poin-poin yang seluruhnya sesuai dengan zakat, atau tepatnya dapat didukung oleh kerja zakat.

Irisan antara SDGs dan Zakat di implementasikan oleh BAZNAS Jawa Barat Menjadi 5 program unggulan mereka yakni, (1) Jabar Peduli, (2) Jabar Sehat, (3) Jabar Mandiri, (4) Jabar Cerdas, dan (5) Jabar Taqwa.

Berdasarkan hasil dari pemaparan kesimpulan di atas, maka penulis akan memberikan sedikit saran terkait Optimalisasi Pendistribusian dan Pendayagunaan Dana Zakat dalam Pelaksanaan Tujuan Program Pembangunan

Berkelanjutan, yaitu: (1) Dalam pengoptimalan Pendistribusian dan Pendayagunaan Dana Zakat untuk pencapaian SDGs perlu adanya sosialisasi mendalam mengenai SDGs dan irisan programnya terhadap lembaga-lembaga amil zakat di bawah naungan BAZNAS Provinsi Jawa Barat; (2) Pelatihan terhadap para amil dalam setiap tahunnya perlu di laksanakan demi terciptanya para petugas amil yang paham akan JUKNIS dan Rencana Strategis mengenai SDGs agar tindak lanjut pelayanan dan pendistribusian kepada para mustahiq makin hari terus meningkat sehingga pencapaian SDGs dapat dilaksanakan secara optimal.

\section{DAFTAR PUSTAKA}

Abdurrahman, Q. (2001). Zakat Dalam Dimensi Mahdhah dan Sosial. Jakarta: Raja Grafindo Persada.

Andarini. (2010). Kamus Besar Bahasa Indonesia. Multazam Mulia Utama, Jakarta. Auda. J. (2008). Maqashid Al-Syariah: An Introduction Guide. London-Washington: International Institute of Islamic Thought. (IIIT)

Bappenas (Badan Perencanaan Pembangunan Nasional). (2006) Petunjuk Teknis Pengajuan Usulan Kegiatan Yang Dibiayai Dari Pinjaman Dan/Atau Hibah Luar 
Negeri, Jakarta

Burke, P. (2011). Sejarah dan Teori Sosial. Yogyakarta: Yayasan Pustaka Obor Indonesia.

Dusuki, A. W. (2005). Corporate Social Responsibility of Islamic Banks in Malaysia: A Synthesis of Islamic and Stakeholders's Perspective. UK, Loughborough University, $\mathrm{PhD}$ Thesis

Didin, H. (2002). "Zakat dalam Perekonomian Modern". Jakarta: Gema Insani Press Ebrahim, M. S. (2016). Institutional status and the underdevelopment of the Muslim world: A juridicio-philosophical critique. Working Paper, Durham University Business School, England, UK

Fehling, M., Nelson, Brett, D., Venkatapuram, Sridhar. (2013). Limitations of the Millennium Development Goals: A Literature Review, Glob Public Health 8(10): 1109-1122

Friedlander, W.A. (1982). Introduction to Social Welfare 3rd Edition. New Jersey: Prentice-Hall.

Hasan, M. (2011). “Manajemen Zakat Model Pengelolaan yang Efektif”, Yogyakarta: Idea Press.

Ibn. A. (2006). Ibn Ashur - Treatise on Maqashid Al - Syariah, trans. Mohamed ElTabir El-Mesawi. London-Washington: International Institute of Islamic Thought (IIIT)

Kementrian Agama RI. (2012). "Modul Penyuluban Zakat".

Kasri., R. A. (2016). Maqasid al-Shariah and Performance of Zakat Institutions. Kyoto Bulletin of Islamic Area Studies

Marta, S. S. dan Fatah, A., Anwar. (1984). Islamic vis a-vis Traditional Banking: A "Fuzzy-set" Approach. Journal of Research in Islamic Economics.

Wardani, R. (2017). Strategi Komunikasi Badan Amil Zakat Nasional dalam Pengumpulan Zakat Maal. Ilmu Dakwah: Academic Journal for Homiletic Studies, 11(1), 151-176. 
F. Amymie, Yaya, D. Sadiah 